Wojciech Stolarz, Damian Piotrowski, Maria Blaszkowska, Barbara Oczko-Grzesik, Jerzy Jaroszewicz, Lucjan Kępa, Barbara Sobala-Szczygiet, Maciej Piasecki, Anna Boron-Kaczmarska

\title{
CLINICAL SIGNIFICANCE OF ASYMPTOMATIC CLOSTRIDIUM DIFFICILE COLONISATION IN PATIENTS UNDERGOING ANTIBIOTIC TREATMENT
}

\author{
ZNACZENIE KLINICZNE NOSICIELSTWA CLOSTRIDIUM DIFFICILE \\ U CHORYCH PODDAWANYCH ANTYBIOTYKOTERAPII
}

\author{
Medical University of Silesia in Katowice \\ Department of Infectious Diseases and Hepatology in Bytom \\ Śląski Uniwersytet Medyczny w Katowicach \\ Katedra i Oddział Kliniczny Chorób Zakaźnych i Hepatologii w Bytomiu
}

\begin{abstract}
BACKGROUND. Clostridium difficile infections become a serious problem in terms of nosocomial infections, as well as a consequence of common use of antibiotics.

AIM. The aim of the study was to evaluate Clostridium difficile carriage in patients admitted to the Clinical Department of Infectious Diseases and Hepatology without acute or chronic diarrhea and to assess the impact of antibiotic treatment on the development of enteritis in hospital. Other factors that may affect the risk of infection were also analyzed.

RESULTS. Fourteen patients (14\%) were carriers of Clostridium difficile at admission. Second assessment taken after fourteen days of antibiotic treatment showed decrease in GDH antigen prevalence to eight subjects (12.1\%). Three patients (3\%) had diarrhea during hospitalization, and the toxins A and/or B were found in them. CONCLUSIONS. The frequency of Clostridium difficile carriage among adults in Poland may be underestimated. Screening for Clostridium difficile GDH antigen may be useful although do not provide definite prognosis of symptomatic disease during ceftriaxone treatment. The risk of Clostridium difficile infection may be reduced mainly by rationalizing antibiotic therapy and following appropriate procedures.
\end{abstract}

Key words: Clostridium difficile, risk factors, nosocomial infections, epidemiology

\section{STRESZCZENIE}

WSTĘP. Zakażenia Clostridium difficile stają się coraz poważniejszym problemem w aspekcie zakażeń wewnątrzszpitalnych, a także jako konsekwencja powszechnego stosowania antybiotyków.

CEL PRACY. Celem pracy było oszacowanie nosicielstwa Clostridium difficile w populacji chorych przyjmowanych do Oddziału Klinicznego Chorób Zakaźnych i Hepatologii bez cech ostrej lub przewlekłej choroby biegunkowej i ocena wpływu antybiotykoterapii na rozwój zapalenia jelit w warunkach szpitalnych. Analizowano także inne czynniki mogące mieć wpływ na ryzyko zakażenia.

WYNIKI. W chwili przyjęcia 14 (14\%) chorych było nosicielami $C$. difficile. W badaniu kontrolnym wykonanym po 14 dniach leczenia antybiotykami obserwowano zmniejszenie częstości dodatniego wyniku badania GDH do 8 osób (12,1\%). U trzech osób (3\%) w trakcie leczenia wystąpiła biegunka, a badaniami stolca wykazano obecność toksyny A i/lub B C. difficile.

WNIOSKI. Częstość nosicielstwa $C$. difficile w grupie osób dorosłych w Polsce może być niedoszacowana. Badania przesiewowe w kierunku obecności antygenu GDH C. difficile mogą być przydatne, ale nie pozwalają jednoznacznie prognozować rozwoju objawowej choroby w trakcie leczenia ceftriaksonem. Ryzyko CDI można ograniczyć przede wszystkim poprzez racjonalizację antybiotykoterapii i przestrzeganie odpowiednich procedur.

Słowa kluczowe: Clostridium difficile, czynniki ryzyka, zakażenie szpitalne, epidemiologia 


\section{INTRODUCTION}

Clostridium difficile, the Gramm-Positive bacterium belongs to the family Clostridioides. They are anaerobic, motile and rod-shaped bacteria, causing the majority of nosocomial infections (1). Its resting forms - spores are resistant to extreme environmental conditions, antibiotics and disinfectants. The spores may remain alive up to 6 months. Initially, the bacteria were not considered pathogens, in 1935 they were described as a component of the gastrointestinal microflora in newborns (2). Clostidium difficile bacteria occur widely in the natural environment, in human and animal gastrointestinal tract and in the meat of commonly bred animals. It is transmitted via the fecal-oral route.

Nowadays, the $C$. difficile infection(CDI-Clostridium difficile infection) is the most frequent nosocomial infection in the USA and other countries $(1,3)$. The infection's frequency has started to raise for two decades and this phenomenon is partially related to the appearance of the endemic strain NAP1 (North American Pulsed Field type1) initially in Canada and USA and then in other regions of the world. The isolation of NAP1 in Poland took place in 2005. The NAP1 strain is characterized by: increased ability to produce enterotoxins A and B, ability to produce binary toxin, fluoroquinolone resistance, increased sensitivity to metronidazole and very high efficiency in spores formation. What is more, the infection with $C$. difficile NAP1 results in more severe course of the disease and higher risk of disease relapse $(1,4)$.

Based on data published by the National Hygiene Department (NHD) the CDI incidence rate in Poland was 30.2/100,000 (2018 year), which meant 11592 registered infections. In years 2014-2018 the incidence rate of CDI in Poland was constantly high: 16.7; 23.3; 30.4 and 30.2 in years 2014-2018 respectively (5).

Ongoing or underwent antibiotic therapy is considered the key factor in the development of the CDI. Antibiotics are divided into high, moderate and low risk groups of causing the disease. Nevertheless, none of them may be considered fully safe. Even substances used in the causative treatment of CDI may potentially induce the disease. Interestingly, already in the 1970's a relation between post-antibiotics inflammation of the large intestine and $C$. difficile has been noted. Other well known CDI risk factors are: age $>65$, hospitalization, residence in caring facilities, chronic intestines' diseases, immunosuppression, PPIs (Proton Pump Inhibitors) and H2-receptor antagonists intake, parenteral nutrition and gastrostomy feeding (6).

The pathogenicity of $C$. difficile is associated with the presence of enterotoxins A, B, and the binary toxin. The toxins destruct the mucosa of the large intestine. Enteritis may hardly be evoked by non-producing strains of $C$. difficile $(4,7)$.

\section{WSTEP}

Bakterie Clostridium difficile należące do rodziny Clostridioides są Gram-dodatnimi, beztlenowymi laseczkami posiadającymi zdolność ruchu, stanowiącymi najczęstszą przyczynę zakażeń szpitalnych (1). Ich formy przetrwalnikowe - spory są odporne na działanie czynników środowiska, antybiotyków i środków dezynfekujących. W sprzyjających warunkach zachowują żywotność do 6 miesięcy. Początkowo bakterii nie uznawano za patogeny, w 1935 roku zostały opisane jako składnik mikroflory przewodu pokarmowego noworodków (2). Występują powszechnie w środowisku naturalnym człowieka, w przewodzie pokarmowym ludzi i zwierząt, mięsie zwierząt hodowlanych. Do zakażenia dochodzi drogą pokarmową lub fekalno-oralną.

Zakażenie $C$. difficile to aktualnie najczęstsze zakażenie szpitalne w USA $i$ innych krajach $(1,3)$. Częstość zakażeń $C$. difficile (CDI $-C$. difficile infection) zaczęła narastać od dwóch dekad i jest po części związana z pojawieniem się epidemicznego szczepu NAP1 (ang. North American Pulsed Field type1), początkowo w Kanadzie i USA, a następnie także w innych rejonach świata. W Polsce po raz pierwszy został on wyizolowany w roku 2005. NAP1 charakteryzuje się zwiększoną zdolnością produkcji toksyn A i B, możliwością produkcji toksyny binarnej, opornością na fluorochinolony, zmniejszoną wrażliwością na metronidazol i sprawniejszym tworzeniem zarodników. Zakażenie tym szczepem wiąże się z większym ryzykiem nawrotów choroby i jej cięższym przebiegiem $(1,4)$.

$\mathrm{Na}$ podstawie danych publikowanych przez NIZP -PZH (Narodowy Instytut Zdrowia Publicznego - Państwowy Zakład Higieny) zapadalność na CDI w Polsce w 2018 roku wynosiła 30,2/100000, co przekłada się na 11592 przypadków zarejestrowanych zachorowań. Zapadalność w naszym kraju utrzymuje się na wysokim poziomie i w kolejnych pięciu latach 2014 - 2018 wynosiła odpowiednio: 16,7; 23,3; 22,7; 30,4 i 30,2 (5).

Kluczowym czynnikiem sprzyjającym rozwojowi CDI jest trwająca lub przebyta antybiotykoterapia. Antybiotyki zostały podzielone na grupy wysokiego, umiarkowanego i niskiego ryzyka wywołania choroby. Nie ma jednak wśród nich takich, które w pełni można by uznać za bezpieczne. Nawet te, które stosowane są w przyczynowym leczeniu choroby mogą potencjalnie ją wywołać. Już w latach siedemdziesiątych XX wieku stwierdzono związek zapaleń jelita grubego po przebytej antybiotykoterapii z CDI. Innymi uznanymi czynnikami ryzyka CDI są: wiek powyżej 65 r.ż., hospitalizacja, pobyt w placówkach opiekuńczych, przewlekłe choroby jelit, immunosupresja, stosowanie inhibitorów pompy protonowej i antagonistów receptora $\mathrm{H} 2$, żywienie pozajelitowe oraz z użyciem sondy żołądkowej i gastrostomii (6). 
CDI may take various clinical pictures. The most benign form is the asymptomatic carrying of the bacteria, which may however result in a higher risk of development of the symptomatic disease and is an epidemiological threat. This form of CDI is usually undiagnosed due to the lack of indications to investigate it. The symptomatic forms of CDI are: benign CDI, self-limiting diarrhea, colitis, pseudomembranous colitis nad colitis fulminant. Typical symptoms are: intensive diarrhea with abdominal pain, fever, leucocytosis. Rarely, the disease may not include diarrhea and has to be distinguished from ileus. The most serious complications od CDI are: intestinal paralysis, megacolon toxicum, sepsis and shock. Incidental extra intestinal CDI manifestations such as: sepsis, intra abdominal infections, perianal abscess nad wound infections are also possible $(8,9)$.

Routinely, patients with diarrhea and those with ileus are tested for CDI. In terms of patients with diarrhea the test sample is liquid stool and in those with suspected CDI- caused ileus the sample would be normal stool or anal smear. The possible diagnostic methods are: detection of the metabolic products of the bacteria, isolation as well as endoscopy and histopathological examination. The most popular test in Poland is a two-stage enzyme immunoassay (EIA) test involving firstly the detection of GDH (glutamine dehydrogenase) and secondly the toxins (8).

Currently no treatment is recommended for asymptomatic $C$. difficile carriers. In symptomatic courses of the disease which is related to an antibiotic treatment, the first-line recommendations are to discontinue antibiotherapy - or if it is impossible - to change the antibiotic. These actions are effective in 23\% of patients. The second-line treatment is antibiotherapy against $C$. difficile with vancomycin or fidaxomicin (according to ASM, SHEA and the Polish Group of Experts). In mild forms of CDI according to ESCMID oral metronidazole may be used, which was considered suboptimal in other recommendations. Furthermore, in the most severe and complicated cases of CDI intravenous metronidazole combined with oral or rectal vancomycin are indicated. In addition to antibiotherapy, in the most severe CDI forms, the bezlotoksumab a monoclonal antibody blocking toxin B is used. While facing the lack of improvement or complications during CDI treatment (megacolon toxicum, perforation) surgery is frequently required. Interestingly, in recurrent CDI (three and more recurrences) transplantation of fecal matter (FMT) is recommended $(8,10,11)$.

\section{AIM}

The objective of this work was to assess the amount of Clostridium difficile carriers in an asymptomatic group of patients admitted to the Department of
Chorobotwórczość $C$. difficile związana jest z obecnością toksyn: enterotoksyny A, cytotoksyny B i toksyny binarnej. Działanie toksyn prowadzi do destrukcji błony śluzowej jelita grubego. Szczepy niemające zdolności produkcji toksyn wyjątkowo rzadko moga wywoływać zapalenia jelit $(4,7)$.

CDI przebiegać może pod różnymi postaciami klinicznymi. Najłagodniejszą formą jest bezobjawowe nosicielstwo, które może jednak wiązać się z większym ryzykiem wystąpienia objawowej postaci choroby i stanowić zagrożenie epidemiologiczne. Ta postać choroby zwykle nie jest rozpoznawana wobec braku wskazań do prowadzenia diagnostyki. Postaci objawowe CDI to: łagodna samoistnie ustępująca biegunka, zapalenie okrężnicy, rzekomobłoniaste zapalenie jelita grubego i colitis fulminant. Typowymi objawami choroby są: nasilona biegunka z bólami brzucha, gorączka, a w badaniach dodatkowych leukocytoza. Rzadko choroba może wystąpić bez objawów biegunki i wymagać różnicowania z niedrożnością jelit. Ciężkim powikłaniem choroby jest porażenna niedrożność jelit, toksyczne rozdęcie okrężnicy (megacolon toxicum), posocznica i wstrząs. Możliwe są również incydentalnie zakażenia $C$. difficile o lokalizacji pozajelitowej przebiegające od początku jako posocznica, zakażenia wewnątrzbrzuszne, ropnie okołoodbytnicze, zakażenia ran $(8,9)$.

Rutynowo badania w kierunku zakażenia $C$. difficile wykonywane są u pacjentów z biegunką i u chorych z objawami niedrożności jelit, kiedy bierze się pod uwagę CDI. W przypadku chorych z biegunką materiałem do badań jest płynny stolec, przy podejrzeniu niedrożności związanej z CDI stolec uformowany lub wymaz z odbytu. Możliwymi do stosowania w diagnostyce metodami są: wykrywanie produktów metabolizmu bakterii, wykrywanie genów, izolacja i typowanie oraz endoskopia i badania histopatologiczne. Najczęściej w naszym kraju wykonywane jest dwustopniowe badanie immunoenzymatyczne polegające na oznaczeniu w pierwszym etapie GDH (dehydrogenazy glutaminianowej) a następnie toksyn (8).

Leczenie nie jest obecnie rekomendowane dla bezobjawowych nosicieli $C$. difficile. W objawowych przebiegach choroby związanych ze stosowaniem antybiotyku w pierwszym rzędzie zaleca się zakończenie antybiotykoterapii lub, gdy to niemożliwe, zmianę antybiotyku. Postępowanie takie jest skuteczne w około $23 \%$ przypadków. Przy niepowodzeniu stosuje się leczenie przyczynowe wankomycyną lub fidaksomycyną (wg zaleceń ASM, SHEA i Polskiej Grupy Ekspertów), w przebiegach łagodnych wg ESCMID stosowany być może doustnie metronidazol, który $\mathrm{w}$ innych rekomendacjach uznano za suboptymalny. W przypadkach najcięższych i powikłanych należy stosować metronidazol dożylnie przy równoczesnym podaniu wankomycyny doustnie, przez sondę dojelitową lub w postaci wlewek doodbytniczych. Jako wspar- 
Infectious Diseases and Hepatology. Moreover, the influence of antibiotherapy used in patients with Lyme disease on development of enteritis was evaluated. Other risk factors of CDI were also analyzed.

\section{MATERIALS AND METHODS}

The investigated group consisted of 100 patients (50 female, 50 male, mean age 54, standard deviation 16.3) hospitalized in the Department of Infectious Diseases and Hepatology, Medical University of Silesia, in 2018. The patients were qualified to undergo an intravenous antibiotic therapy against the Lyme disease (Table I).

Table I. Patients' characteristics.

Tabela I. Charakterystyka pacjentów

\begin{tabular}{|l|c|}
\hline Parameter & $\begin{array}{l}\text { Observed group } \\
(\mathrm{n}=100)\end{array}$ \\
\hline Age [years] ${ }^{1}$ & $54.0(16.3)$ \\
\hline WBC [G/1] $]^{1}$ & $6.55(1.90)$ \\
\hline Men (\%) & $50 \%$ \\
\hline GDH-positve primarily (\%) & $14 \%$ \\
\hline GDH-positive at the end of study (\%) & $12.1 \%{ }^{2}$ \\
\hline
\end{tabular}

${ }^{1}$ average and standard deviation, ${ }^{2}$ the second GDH-test nad $C$. difficile toxin-test in stool was done by 66 patients. The other 34 of them refused to give the second sample of stool.

Patients who underwent diarrhea - regardless of its etiology -8 or less weeks before admission were excluded from the study. Acclaimed risk factors of CDI were assessed basing on a questionnaire (Table II). cie antybiotykoterapii u osób z wysokim ryzykiem nawrotu choroby stosuje się przeciwciała monoklonalne blokujące działanie toksyny B - bezlotoksumab. W przypadku braku poprawy lub powikłań (toksyczne rozdęcie okrężnicy, perforacja jelita) postępowaniem z wyboru jest leczenie operacyjne. Przy zakażeniach nawrotowych (trzy i kolejne nawroty) zalecana jest transplantacja mikrobiontów kałowych (ang. fecal microbiota transplant - FMT) $(8,10,11)$.

\section{CEL PRACY}

Celem pracy było oszacowanie częstości nosicielstwa Clostridium difficile w grupie osób przyjmowanych do Oddziału Klinicznego Chorób Zakaźnych i Hepatologii bez cech ostrej lub przewlekłej choroby biegunkowej i ocena wpływu antybiotykoterapii stosowanej w leczeniu choroby z Lyme na wystąpienie zapalenia jelit. Przeanalizowano ponadto inne czynniki mogące mieć wpływ na ryzyko zakażenia.

\section{MATERIAŁ I METODY}

Analizą objęto pacjentów hospitalizowanych w roku 2018 roku w Klinicznym Oddziale Chorób Zakaźnych i Hepatologii w Bytomiu, Śląskiego Uniwersytetu Medycznego w Katowicach.

Badanie dotyczyło 100 osób (50 kobiet i 50 mężczyzn, średnia wieku 54 lata, odchylenie standardowe 16,3) przyjętych do oddziału w trybie planowym, z uprzednio rozpoznaną boreliozą z Lyme, zakwalifikowanych do leczenia antybiotykami dożylnymi (Tab. I).

Table II. Comparison between the group with GDH-positive and GDH-negative test at admission to the hospital.

Tabela II. Porównanie grupy z obecnym antygenem GDH C. difficile przy przyjęciu i grupy bez antygenu GDH

\begin{tabular}{|l|c|c|c|}
\hline Parameter & $\begin{array}{c}\text { GDH antigen present } \\
\text { at admission } \\
(\mathrm{n}=14)\end{array}$ & $\begin{array}{c}\text { GDH antigen absent } \\
\text { at admission } \\
(\mathrm{n}=86)\end{array}$ \\
\hline Age [years] & $52.2(21.6)^{1}$ & $54.3(15.4)^{1}$ & 0.815 \\
\hline WBC [G/l] & $6.16(1.58)^{1}$ & $6.61(1.96)^{1}$ & 0.342 \\
\hline Men & $85.7 \%$ & $44.2 \%$ & 0.004 \\
\hline PPIs' intake before hospitalization & $14.3 \%$ & $4.7 \%$ & 0.1622 \\
\hline H2-antagonists intake before admission & $14.3 \%$ & $0 \%$ & 0.0001 \\
\hline Antibiotherapy before admission & $28.6 \%$ & $2.3 \%$ & 0.0332 \\
\hline Probiotics intake before admission & $14.3 \%$ & $62.8 \%$ & 0.0934 \\
\hline Probiotics intake during hospitalization & $85.7 \%$ & $0 \%$ & $0 \%$ \\
\hline Immunosuppression & $0 \%$ & $0 \%$ & 0 \\
\hline Other hospitalization up to 30 days before admission & $0 \%$ & 0 & 0 \\
\hline Diarrhea in the last 30 days before admission & & 0 & 0 \\
\hline
\end{tabular}

${ }^{1}$ average and standard deviation 
Routine laboratory tests were conducted such as: blood morphology, CRP, protein level, electrophoresis and twice the two-stage EIA of the stool searching for the CDI. The EIA test has been done before the antibiotics were administered, after 14 days of therapy or in the event of diarrhea. In the first stage of the EIA test the concentration of GDH was determined (the metabolic product of $C$. difficile), in the event of a positive result - a test detecting toxins $\mathrm{A} / \mathrm{B}$ was conducted. Immunocard $C$. difficile GDH nad Immunocard Toxins $\mathrm{A} \& \mathrm{~B}$ were used respectively.

Positional measures were used to describe the results. The analysis was conducted using the Statistica program (TIBCO Software Inc (2017) Statistica data analysis software system, version 13. http://statistica. io). Data are presented as an average \pm standard deviation or percentage (\%). The level of significance was $\mathrm{p}<0.05$.

\section{RESULTS}

The analysis considered 100 patients hospitalized in the Department of Infectious Diseases and Hepatology in order to undergo an antibiotic treatment of an earlier identified Lyme disease. The majority of patients suffered from Lyme joints' inflammation and neuroborreliosis. According to the Indications of the Polish Experts of Infectious Diseases, ceftriaxone 2 grams i.v. was used for 21-28 days in these patients. Moreover, patients with Lyme disease treated with other antibiotics were not taken into account, as the therapy was partially conducted in the outpatient clinic or partially at home with oral medicaments.

At the admission the GDH-test was positive at $14(14 \%)$ of patients (but without presence of $\mathrm{A} / \mathrm{B}$ toxins). Men who chronically used H2-antagonists and underwent some antibiotic and probiotic treatment before admission prevailed in this group (Table II). After 14 days of treatment with ceftriaxone the follow-up GDH-test was positive in $12,1 \%$. Diarrhea with presence of $C$. difficile $\mathrm{A} / \mathrm{B}$ toxins occurred in three persons during treatment. At admission in these three patients the GDH-test was positive without the presence of toxins. No diarrhea was noted in patients with negative GDH-test.

\section{DISCUSSION}

The presence of $C$. difficile in human gastrointestinal tract is detected already in the youngest children and reaches up to $70 \%$ in the group to 18 -months-olds. In adults the prevalence is estimated $1-3 \%$ (12). In studied group the amount of $C$. difficile carriers was significantly higher - $14 \%$. This may be due to the fact that patients with Lyme disease might have had
Z analizy zostały wykluczone osoby z trwającą i przebytą do 8 tygodni wcześniej chorobą biegunkową, niezależnie od faktu czy ustalono, i jaka była jej etiologia. Na podstawie ankiety określono występowanie uznanych czynników ryzyka zakażenia $C$. difficile (Tab. II). U chorych wykonano rutynowe badania laboratoryjne obejmujące: morfologię, OB, CRP, poziom białka i elektroforezę oraz dwukrotnie dwuetapowe badanie immunoenzymatyczne (EIA) kału w kierunku zakażenia $C$. difficile - przed rozpoczęciem i w 14 dniu antybiotykoterapii lub w przypadku wystąpienia biegunki. W badaniu pierwszego etapu oznaczano obecność antygenu GDH (dehydrogenaza glutaminianowa - produkt metabolizmu bakterii), a następnie w przypadku dodatniego wyniku badano toksyny A/B. Stosowano odpowiednio testy Immunocard $C$. difficile GDH i Immunocard Toxins A \& B.

Do opisu wyników badań wykorzystano miary pozycyjne. Analiza została przeprowadzona z wykorzystaniem oprogramowania Statistica (TIBCO Software Inc. (2017). Statistica (data analysis software system), version 13. http://statistica.io.). Dane przedstawiono jako średnia \pm odchylenie standardowe lub odsetek (\%). Za poziom istotności przyjęto $\mathrm{p}<0,05$.

\section{WYNIKI}

Analizie poddano 100 kolejnych chorych hospitalizowanych w roku 2018 w Klinicznym Oddziale Chorób Zakaźnych i Hepatologii SUM w związku z uprzednio rozpoznaną boreliozą z Lyme i zakwalifikowanych do leczenia antybiotykami. Dominowali pacjenci z rozpoznaną postacią stawową choroby i neuroboreliozą. Leczenie przebiegało zgodnie z rekomendacjami PTEiL$\mathrm{ChZ}$ z zastosowaniem ceftriaksonu w dawce dobowej 2 g i.v. przez okres 21-28 dni. Pacjenci z rozpoznaną boreliozą leczeni innymi antybiotykami nie byli analizowani, ponieważ terapia prowadzona była w całości lub po części w warunkach ambulatoryjnych doustnymi postaciami leków.

W chwili przyjęcia do oddziału u 14 (14\%) chorych stwierdzono obecność w stolcu antygenu GDH C. difficile, bez obecności toksyny A/B. W grupie tej dominowali mężczyźni używający antagonistów receptora H2, którzy przed przyjęciem do szpitala leczeni byli antybiotykami i probiotykami (Tab. II). W badaniu kontrolnym wykonanym po 14 dniach leczenia antybiotykami obserwowano zmniejszenie częstości dodatniego wyniku badania GDH do $12,1 \%$. U trzech osób w trakcie leczenia wystąpiła biegunka, a badaniami stolca wykazano obecność toksyny A i/lub B $C$. difficile. Wyjściowo prezentowały one obecność antygenu bez obecności toksyny. Nie obserwowano objawów biegunki w grupie chorych przyjętych do szpitala $\mathrm{z}$ nieobecnym antygenem $C$. difficile. 
numerous attempts of antibiotic treatment before the study. Exposure to risk factors such as: PPIs intake, immunosuppression or earlier hospitalizations was not significantly greater in the group of examined carriers. However, antibiotherapy in the past, probiotics and $\mathrm{H} 2$-antagonists intake were notably more prevalent in the group of $C$. difficile carriers. The mean age of carriers was 52.2 years and non-carriers 54.3 years. Moreover, the percentage of male patients was $85.7 \%$ and $44.2 \%$ respectively (this difference was statistically significant). Interestingly, the percentage of patients with positive GDH-test decreased slightly - down to $12.1 \%$ after 14 days of intravenous ceftriaxone intake. The 3th generation of cephalosporines, in contrast to the 1st and 4th generation, are classified as antibiotics with high risk in CDI-triggering. The slight decrease may be an effect of a low quantity of the studied group. Although, it is speculated, that some cephalosporins may have a suppressive effect on growth of $C$. difficile $(13,14)$.

Hospitalization is considered a strong risk factor of CDI. Therefore, the so-called: bed-day parameter is often used to evaluate the scale of the nosocomial CDI problem. According to the data from the EUCLID project, in Europe in year 2013, 17.2 cases of CDI were reported in 10,000 bed-days. However in 2013 in Poland the index was 48.3. The percentage of $C$. difficile carriers among hospitalized persons is estimated to 20$40 \%$ (15). In the investigated group the percentage was $12,4 \%$ after 14 days of treatment. The main hospital reservoirs of the pathogen are: people with CDI, medical staff and medical equipment or patient's environment contaminated with $C$. difficile spores $(16,17)$. Medical staff's contact with patients suffering from CDI results in the presence of the bacteria on the staff's hands in $25 \%$ of the cases. Interestingly, no increased amount of $C$. difficile carriers were observed among medical personnel (18). The essential aspects of hospital acquired CDI are also: the conditions of hospitalization, hospitalization in rooms for many people or the lack of an individual toilets. What is more, the isolation of patients with CDI is not always possible, it frequently happens that these patients are isolated in cohorts. Due to these actions, the risk of relapse becomes greater. The risk of a nosocomial CDI is increased while patients are in shared rooms and wards are being overcrowded $(19,20)$. Until now, there are no official recommendations to identify $C$. difficile carriers at admission to the hospital routinely, however this issue is being currently discussed (21). Procedure compliance and medical staff's awareness result in a measurable degree of prevention of CDI transmission (22). What is equally crucial is the education and cooperation among patients and hospital's personnel (23).

\section{DYSKUSJA}

Obecność $C$. difficile w przewodzie pokarmowym człowieka stwierdzana jest już u najmłodszych dzieci i sięga $70 \%$ w grupie do 18 miesiąca życia, u dorosłych szacowana jest na 1-3\% (12). W badanej grupie chorych częstość nosicielstwa w chwili przyjęcia do oddziału była znacząco wyższa i osiągnęła $14 \%$. Wynikać to może z faktu, że pacjenci z boreliozą kwalifikowani do leczenia szpitalnego mieli już za sobą wcześniejsze próby antybiotykoterapii w trybie ambulatoryjnym. W grupie nosicieli nie stwierdzono statystycznie znamiennego większego narażenia na takie uznane czynniki ryzyka zakażenia jak: stosowanie inhibitorów pompy protonowej (IPP), immunosupresji, przebyte w ostatnim czasie hospitalizacje; wykazano natomiast częstsze stosowanie antybiotyków, probiotyków i antagonistów receptora H2. Wiek średni w tej grupie wynosił 52,2 roku, a w grupie niebędącej nosicielami 54,3 roku. Odsetek mężczyzn wynosił odpowiednio 85,7\% i $44,2 \%$ (ta różnica była istotna statystycznie). Warto zauważyć, że odsetek osób z dodatnim antygenem $C$. difficile, po dwutygodniowym stosowaniu ceftriaksonu, uległ niewielkiemu zmniejszeniu - do 12,1\%. Cefalosporyny III generacji, w odróżnieniu od generacji I i IV, zaliczane są do antybiotyków wysokiego ryzyka wywoływania zakażeń $C$. difficile i obserwowany spadek wynikać może z małej liczebności badanej grupy. Rozważa się jednak hamujące działanie niektórych spośród cefalosporyn na wzrost $C$. difficile $(13,14)$.

Sam fakt hospitalizacji uznany jest za istotny czynnik ryzyka CDI. Często wykorzystywanym w celu określenia skali problemu parametrem jest określenie liczby przypadków zachorowań na liczbę tzw. łóżko -dni. Zgodnie z danymi pochodzącymi z projektu EUCLID, w Europie w 2013 roku średnio stwierdzano 17,2 przypadku CDI na 10000 tóżko-dni, podczas gdy w Polsce w tym samym czasie wskaźnik ten wynosił 48,3. Nosicielstwo wśród hospitalizowanych szacowane jest na $20-40 \%$ (15). W badanej grupie po 14 dniach leczenia wynosił $12,4 \%$. W warunkach szpitalnych rezerwuarem patogenu są chorzy z CDI, nosiciele, personel medyczny oraz zanieczyszczony sporami sprzęt medyczny i otoczenie chorego $(16,17)$. Kontakt personelu z chorym z CDI skutkuje w ok. $25 \%$ obecnością spor bakterii na rękach. Nie stwierdzono jednak częstszego nosicielstwa patogenu wśród badanego personelu medycznego (18). Istotnym zagadnieniem są warunki hospitalizacji, przebywanie chorych w salach wieloosobowych, brak indywidualnego WC na sali. Nie zawsze możliwa jest też izolacja kontaktowa pacjentów z CDI, często konieczne jest kohortowanie takich chorych. Zwiększa to ryzyko nawrotów choroby wskutek wzajemnych nadkażeń. Ryzyko zakażenia szpitalnego rośnie w przypadku wspólnych sal cho- 
The use of probiotics was analyzed in terms of CDI prophylaxis. Primarily, the carriers group seemed to use probiotics more, however this might be connected to their earlier antibiotics intake. The potential benefits of probiotics intake are difficult to estimate due to the small size of the investigated group. In three patients who took probiotics and primarily were GDH-negative, the antigen appeared after 14 days of applied antibiotherapy. In six cases, where the GDH-test was positive at admission, it disappeared during antibiotic therapy with probiotics. Three of our patients with positive toxins and symptoms of the CDI were prescribed probiotics as prophylaxis. The actual recommendations do not include the use of probiotics in order to colonize the large intestine's mucosa nor in the prevention either in the CDI treatment (24). The most frequently mentioned species in the CDI prophylaxis and treatment are Lactobacillus and Saccharomyces boullardi. Individual cases of infections caused by probiotics were described $(25,26)$.

Considering the CDI risk factors in the investigated group, such as: older age, PPIs and $\mathrm{H} 2$-antagonists intake, immunosuppressive treatment, comorbidities - no significant differences in patients in whom antibiotherapyrelated diarrhea occurred and did not occur were observed. Similarly, no correlation with the emergence/ disappearance of the GHD and/or toxins was noted.

\section{CONCLUSIONS}

The amount of $C$. difficile carriers in Poland may be underestimated. On one hand screening GDH-tests appear to be useful, on the other hand however they do not predict the development of symptomatic disease during treatment with ceftriaxone. Antibiotherapy rationalization, risk awareness and procedure compliance result in lowering the risk of Clostridium difficile infection in hospitalized patients.

\section{REFERENCES}

1. Miller BA, Chen LF, Sexton DJ, et al. Comparison of the burdens of hospital-onset, healthcare facilityassociated Clostridium difficile infection and of healthcare-associated infection due to methicilinresistant Staphylococcus aureus in community hospitals. Inf Control Hosp Epidemiol, 2011; 32: 387-390.

2. Hall IC, O'Toole E. Intestinal flora in newborn infant - with a description of a New pathogenic anaerobe, Bacillus difficilis. Am J Dis Child 1935; 49: 390-402.

3. Surawucz CM, Brandt LJ, Binion DG et al. Guidelines for diagnosis, treatment, and prevention of Clostridium difficile infections. Am J Gastroenterol, 2013;108(4):478-498. rych i wysokiego wskaźnika obłożenia łóżek $(19,20)$. Jak dotąd nie zaleca się identyfikowania nosicieli $C$. difficile ze względów epidemiologicznych, ale problem jest dyskutowany (21). Przestrzeganie odpowiednich procedur przez personel i świadomość zagrożenia skutkują wymiernymi efektami w zapobieganiu transmisji zakażenia (22). Nie do przecenienia jest także edukacja chorych i ich współdziałanie (23).

$\mathrm{W}$ badanej grupie analizowano stosowanie probiotyków w aspekcie profilaktyki CDI. Wyjściowo wśród nosicieli zakażenia było więcej osób stosujących probiotyki niż w grupie niezakażonych, łączyło się to jednak najczęściej również z antybiotykoterapią. Trudno oszacować w naszym materiale potencjalne korzyści lub ich brak ze względu na małą liczebność grup. U trzech chorych stosujących probiotyki, którzy wyjściowo nie mieli wykrywalnego antygenu GDH, pojawił się on po 14 dniach antybiotykoterapii. W sześciu przypadkach, gdzie antygen był na wstępie wykrywany, zniknął $\mathrm{w}$ trakcie antybiotykoterapii połączonej z probiotykiem. Trzej pacjenci, u których pojawiła się toksyna i objawy chorobowe otrzymywali zapobiegawczo probiotyk. Aktualne rekomendacje nie uwzględniają stosowania probiotyków w celu kolonizacji błony śluzowej jelita grubego zarówno w profilaktyce jak i leczeniu CDI (24). Wśród gatunków badanych pod kątem zastosowania w prewencji i w terapii najczęściej wymienia się Lactobacillus i Saccharomyces boulardii. Opisywano także pojedyncze przypadki zakażeń wywołanych przez probiotyki $(25,26)$.

Przeanalizowano w badanej grupie inne powszechnie uznane czynniki ryzyka zakażenia $C$. difficile jak: starszy wiek, leki zwiększające pH przewodu pokarmowego, leczenie immunosupresyjne, choroby towarzyszące - nie stwierdzając jednak różnic między osobami, u których rozwinęła się biegunka w trakcie antybiotykoterapii, a pacjentami, u których nie doszło do rozwoju objawowej choroby. Podobnie nie stwierdzono korelacji z pojawieniem się/zniknięciem antygenu i/lub toksyny $C$. difficile

\section{WNIOSKI}

Częstość nosicielstwa $C$. difficile w grupie osób dorosłych w Polsce może być niedoszacowana. Badania przesiewowe w kierunku obecności antygenu GDH $C$. difficile mogą być przydatne, ale nie pozwalają jednoznacznie prognozować rozwoju objawowej choroby w trakcie leczenia ceftriaksonem. Ryzyko CDI można ograniczyć przede wszystkim poprzez racjonalizację antybiotykoterapii. Świadomość ryzyka CDI i przestrzeganie odpowiednich procedur skutkuje ograniczeniem liczby przypadków zakażeń związanych z hospitalizacją. 
4. Pituch H, Bakker D, Kuijper E. First isolation of Clostridium difficile PCR-ribotype 027/toxinotype III in Poland. Pol J Microbiol 2008; 57: 267-268.

5. Choroby Zakaźne i Zatrucia w Polsce w 2018 roku. Narodowy InstytutZdrowia Publicznego-Państwowy Zakład Higieny i Główny Inspektor Sanitarny: Warszawa, 2019. (www.pzh.gov.pl) wwwold.pzh. gov.pl/oldpage/epimeld/2018/Ch 2018.pdf

6. Mizui T, Teramachi H, Tachi T, et al. Risk factors for Clostridium difficile-associated diarrhea and the effectiveness of prophylactic probiotic therapy. Pharmazie, 2013; 68(8): 706-710.

7. Davies KA, Longshaw CM, Davis GL, et al. Underdiagnosis of Clostridium difficile cross Europe: the European, multicentre, prospective, biannual, point-prevalence study of Clostridium difficile infection in hospitalised patients with diarrhoea (EUCLID). Lancet Infect Dis, 2014; 14: 1208-19. doi: 10. 1016/1473-3099(14)70991-0.

8. Martirosian G, Hryniewicz W, Ozorowski T, et al. Zakażenia Clostridioides (Clostridium) difficile: epidemiologia, diagnostyka, terapia, profilaktyka. Narodowy Instytut Leków, 2018. http://antybiotyki. edu.pl/wp-content/uploads/Rekomendacje/ clostridium-difficile-2018-3_12_net.pdf

9. Mattila E,ArkkilaP, Mattila PS, et al. Extraintestinal Clostridium difficile infections. Clin Infect Dis, 2013; 57(6): e148-153.

10. Fitzpatrick F., Skally M., Brady M., et al. European practice for CDI treatment. In: Updates on $C$. difficile in Europe. Ed. Mastrantonio P. and Rupnik M. Advances in microbiology, infectious diseases and public health. 2018;8:117-137.

11. Napolitano L., Edmiston C. Clostridium difficile disease: diagnosis, pathogenesis and treatment update. Surgery 2017;162(2):325-348.

12. Rożkiewicz D. Zakażenia Clostridium difficile rosnącym zagrożeniem u dzieci. Forum Zakażeń 2012;3(4):165-175.

13. Wilcox M, Chalmers J, Nord C, et al. Role of cephalosporines In the era of $c$. difficile infection. $\mathrm{J}$ Antimicrob Chemother, 2017;72:1-18.

14. Baines S, Chilton C, Crowther G, et al. Evaluation of antimicrobial activity of ceftaroline against $C$. difficile and propen sity to induce CDI in an in vitro human Gut model. J Antimicrob Chemother 2013;58:133-136.

15. Hryniewicz W, Martirosian G, Ozorowski T. Zakażenia Clostridium difficile. Diagnostyka, terapia, profilaktyka. Warszawa: Narodowy Instytut Leków, 2011, 12-14.

16. Lanzas C, Dubberke ER. Effectiveness of screening hospital admissions to detect asymptomatic carriers of Clostridium difficile: a modeling evaluation. Infect Control Hosp Epidemiol 2014;35(1):10-15
17. Landelle $C$, Verachten $M$, Legrand $P$, et al. Contamination of Healthcare workers' hands with Clostridium difficile spores after caring for patients with $C$. difficile infection. Infect Control Hosp Epidemiol 2014;35(1):10-15.

18. Friedman ND, Pollard J, Stupart D, et al. Prevalence of Clostridium difficile colonization among healthcare workers. BMC Infect Dis 2013;13:459

19. Echaiz JF, Veras L, Zervos M, et al. Hospital roommates and development of health care-onset Clostridium difficile infection. Am J Infect Control 2014;42(10):1109-1111.

20. Ahyow LC, Lambert PC, Jenkins DR, et al. Bed occupancy rates and hospital-acquired Clostridium difficile infection: a kohort study. Infect Control Hosp Epidemiol 2013;34(10):1062-1069.

21. Curry SR, Muto CA, Schlackman JL, et al. Use of multilocus variable number of tandem repeats analysis genotyping to determine the role of asymptomatic carriers in Clostridium difficile transmission. Clin Infect Dis 2013;57(8):10941102.

22. Mermel LA, Jefferson J, Blanchard K, et al. Reducing Clostridium difficile incidence, colectomies, and mortality In the hospital setting: a cuccessful multidisciplinary approach. It Comm J Qual Patient Saf 2013;39(7):298-305.

23. Pokrywka M, Feigel J, Douglas B et al. A bundle strategy including patient hand hygiene to decrease Clostridium difficile infections. Medsurg Nurs 2014;23(3):145-148.

24. Rodriguez H, Miller JE. Do prophylactic probiotics prevent the incidence of Clostridium difficile colitis infection in hospitalized patients? J Okla State Med. Assoc 2019;112(1):18-19.

25. Enache-AngoulvantA, Hennequin C. Invasive Saccharomyces infection: a comprehensive review. Clin Infect Dis 2005; 41: 1559-1568.

26. Gouriet F, Million M, Henri M, et al. Lactobacillus rhamnosus bacteremia: an emerging clinical entity. Eur J Clin Microbiol Infect Dis 2012; 31: 24692480.

Received: 23.12.2019

Accepted for publication: 11.02.2020

Otrzymano: 23.12.2019 r.

Zaakceptowano do publikacji: 11.02.2020 r.

\section{Adres do korespondencji:}

Address for correspondence:

Wojciech Stolarz

Katedra i Oddział Kliniczny Chorób Zakaźnych i Hepatologii SUM,

Aleja Legionów 49, 41-902 Bytom,

tel. 0322819241

e-mail:wsto@wp.pl 